pletely unnecessary mini-panic here recently. The hereditary disease strikes people who lack a particular enzyme (G6PD), one which protects red blood cells against the noxious effects of the fava bean and other materials, and thus prevents anaemia. It is by no means limited to Jews, as it affects, among others, Scandinavians, American Negroes and groups in South-east Asia. But among Jews it is limited almost exclusively to people who have lived in Iraq, Kurdistan or Iran.

In spite of this well established fact, the Ministry of Health last week dramatically announced that all Israelis should refrain from eating fava beans (which, together with common medi- cines like sulpha drugs and aspirin, trigger favism). The sale of fava beans diminished, of course, but rose again when citizens were informed that unless they came from those three countries they could eat the lentils to their heart's content. A screening programme now being carried out at local hospitals should clarify the problem for all Israelis in the course of the next few years.

- The dangers of inbreeding within a particular ethnic group are starkly emphasised by the problems facing the Samaritans, an ancient Holy Land sect which now numbers some 450 , half of whom live in Holon, a suburb of Tel Aviv, while the other half live in the
West Bank town of Nablus. Because $58 \%$ of Samaritan marriages take place betwcen members of the same family, an abnormal number of physically or mentally handicapped children is born to members of the community. New blood in the form of five Jewish brides has improved the genetic mix in recent years, but the community still remains dangerously inbred.

Yet these people, descendants of the Good Samaritan, show an extraordinary will to survive. They now number more than three times as many as they did a hundred years ago, when The Times reported that there were only 135 Samaritans in the entire country.

\title{
correspondence
}

\section{Mediterranean mercury}

SIR,-The article by Alexander Dorozynski (April 17) on the "Mediterranean poison fish forecast" made by Dr Maurice Aubent, Director of the Centre d'Etudes et de Recherches des Biologie et Oceanographie Médicale in Nice states that more than 1 p.p.m. of methylmercury is present in nine species of fish caught in the Mediterranean. There is a calculation attributed to Dr Aubert worth quoting: "Since it has been found that only 4 to $5 \%$ of mercury absorbed is fixed in the organism, the weekly absorption of food containing $2 \mathrm{mg}$ of mercury will result in a fixation of $80 \mu \mathrm{g}$. At this rate the lethal dose is reached about 20 years". The lethal dose according to $\mathrm{Dr}$ Aubert is $80 \mathrm{mg}$, which is reached in the fisherman by the following equation:

\section{$2 \mathrm{mg} \times 0.04 \times 52 \times 20$}

This calculation has no scientific basis. First Japanese data indicate that $80 \mathrm{mg}$ is the lowest toxic body burden and not the lethal dose. Second abundant data reviewed by expert committees show that approximately $95 \%$ of the ingested methylmercury is absorbed from the gastrointestinal tract and that the average half life of methylmercury in the human body is 70 days. This means that the body burden of the fisherman in question will be $24 \mathrm{mg}$ after 6 months, $28 \mathrm{mg}$ after 1 year and $28.86 \mathrm{mg}$ in the steady state when he will excrete exactly $2 \mathrm{mg}$ of mercury a week.

The same criticism applies to $\mathrm{Dr}$ Aubert's calculation for the child victims of Minamata. He also misquotes the lowest level of hair mercury associ- ated with intoxication. According to the work of the Swedish Expert Group on the Minamata epidemic, $60 \mu \mathrm{g} / \mathrm{g} \mathrm{Hg}$ signals the danger of intoxication rather than twice the level $(7.39 \mu \mathrm{g} / \mathrm{g})$ found by Dr Aubert in a fisherman. Based on the relationship between the concentration of mercury in hair, the blood level, the body burden and the weekly dose, his fishermen probably had a body burden of less than $10 \mathrm{mg}$, which assuming steady state conditions was the result of the weekly consumption of $0.7 \mathrm{mg}$ mercury as methylmercury. Yours sincerely,

MRC Laboratories,

L. MAGOS

\section{Carshalton, UK}

In line 9 of paragraph 5 of the article, $25 \mu \mathrm{g}$ should read $25 \mathrm{mg}$.

\section{Plants}

SIR,-Rain forests, vanishing wild life and the destruction of rare wild flowers by reservoirs are all sure of space in periodicals and funds for conservation on grounds of preserving the gene pool, vet garden varieties of vegetables are in greater danger of extermination. The FAO are now searching Turkey for hardy varieties still grown by peasants, but Europe is destroying her genetic heritage from the best of motives.

Modern methods of seed storage make it possible to keep packets "in mothballs" for as long as 200 years and I suggest that stocks of all deleted varieties should be donated to a National Seed Library, ideally sited at a University such as Reading, from which they would be available to plant breeders and enthusiasts. We would be glad to hear from those who are seriously interested in this project and from Foundations and others who would make grants to start a World Vegetable Fund, like the World Wildlife Fund, but more urgent in view of the greater pace of extermination. Yours sincerely, LaWRENCE D. Hills

Henry Doubleday Research

Association,

Braintree, Essex, UK

\section{Methinks he doth edit too much}

SiR,-Every new scientific journal to appear sports a long list of associate editors, members of the editorial board, advisory editors or whatever. These are generally academics who are presumed to guarantee the quality of the product; my suspicion is that they rarely do anything beyond collect an annual fee, referee a paper or two and line their shelves with complimentary copies of the journal which they don't read. One journal that I see has an advisory board of six in addition to twenty or thirty associate editors; all the advisors have a Nobel Prize but only one in a field close to that of the journal.

I don't begrudge a fellow one sinecure, but it is my impression that some hold five or ten editorial positions. How about a prize for the man with the most appearances?

$$
\text { Yours faithfully, }
$$

$$
\text { M. Charles }
$$

\section{Boston, Mass}

A year's free subscription for he or she whose nominee tops the list-but nothing for the nominee, whose shelves are probably full already. Entries by July 1-Ed. 